\title{
OXYTOCIN DIRECTLY STIMULATES CORTICOSTERONE SECRETION BY DISPERSED RAT ADRENAL ZONAE FASCICULATA AND RETICULARIS CELLS: EVIDENCE FOR THE SPREADING OF THE OXYTOCIN-EVOKED SIGNAL FROM RESPONSIVE TO UNRESPONSIVE CELLS
}

\author{
Jerzy B. Warchol ${ }^{1}$, Krystyna Filipiak $^{1}$, Elzbieta IgnaszaK ${ }^{1}$, Gastone G. Nussdorfer ${ }^{2}$ and Ludwik \\ K. MalendowiCZ ${ }^{1}$ \\ ${ }^{1}$ Department of Histology and Embryology, School of Medicine, 60781 Poznan, Poland, and ${ }^{2}$ Department of Anatomy, University \\ of Padua, 35121 Padua, Italy
}

\begin{abstract}
Oxytocin enhanced basal corticosterone secretion by dispersed rat adrenal zonae fasciculata and reticularis cells, the maximum effect being observed at a concentration $10^{-9}-10^{-8} \mathrm{M}$. Video-imaging analysis revealed the existence of a small population of isolated cells (about $5 \%$, responding to the addition of oxytocin $\left(10^{-8} \mathrm{M}\right)$ by a marked rise in the cytosolic free $\mathrm{Ca}^{2+}$ concentration. An interesting phenomenon was also noted, suggesting the propagation of the oxytocin-evoked signal from activated to non-activated cells.
\end{abstract}

The role of oxytocin in the regulation of adrenocortical function is far from being fully understood (see 4, for review). The presence of oxytocin has been demonstrated in the adrenal glands of many mammalian species, including the rat (1): immunoreactive oxytocin is distributed throughout the entire cortex with the most intense staining in zona glomerulosa, while in the medulla only norepinephrine cells are immunopositive. Such a localization of oxytocin suggests the involvement of this peptide in the regulation of adrenal cortex function. Accordingly, Hinson et al. (2) demonstrated a direct stimulatory effect of oxytocin on aldosterone secretion. Here we report findings showing that oxytocin exerts a direct glucocorticoid secretagogue effect on dispersed rat adrenal zonae fasciculata and reticularis cells (inner adrenocortical cells), by activating intracytoplasmatic $\mathrm{Ca}^{2+}$ redistribution in a small population of responsive cells.

\section{MATERIALS AND METHODS}

The adrenal glands removed from adult female Wistar rats were decapsulated, and isolated inner adrenocortical cells were obtained by sequential collagenase digestion and mechanical dispersion (8). The viability of isolated cells was checked by the trypan-blue exclusion test and found to be higher than $92 \%$.

Dispersed cells obtained from 6 rats were pooled to obtain a single cell suspension, and 6 cell preparations were employed. Aliquots of each cell suspension $\left(10^{5}\right.$ cells $\left./ \mathrm{ml}\right)$ were incubated with oxytocin (Gedeon-Richter, Budapest, Hungary). The incubation was carried out for $60 \mathrm{~min}$ in a shaking bath at $37^{\circ} \mathrm{C}$ in an atmosphere of $95 \% \quad \mathrm{O}_{2}$ and $5 \% \mathrm{CO}_{2}$. Corticosterone was measured in the medium by a specific radioimmunoassay (5). Intraand inter-assay variations were $6 \%$ and $8 \%$, respectively.

Other dispersed inner adrenocortical cells were loaded with fura-2, as described by Mason et al. (6). Loaded cells in Hepes buffer were transferred into poly-L-lysine-coated measuring vessels placed under a Nikon Diaphot microscope. This inverted microscope was connected to a dynamic videoimaging Magical System (Joyce-Loebel, Gateshead, U.K.). After initial recording of intracellular $\mathrm{Ca}^{2+}$ concentration, oxytocin was added at a concentration ranging from $10^{-8}$ to $10^{-6} \mathrm{M}$. 


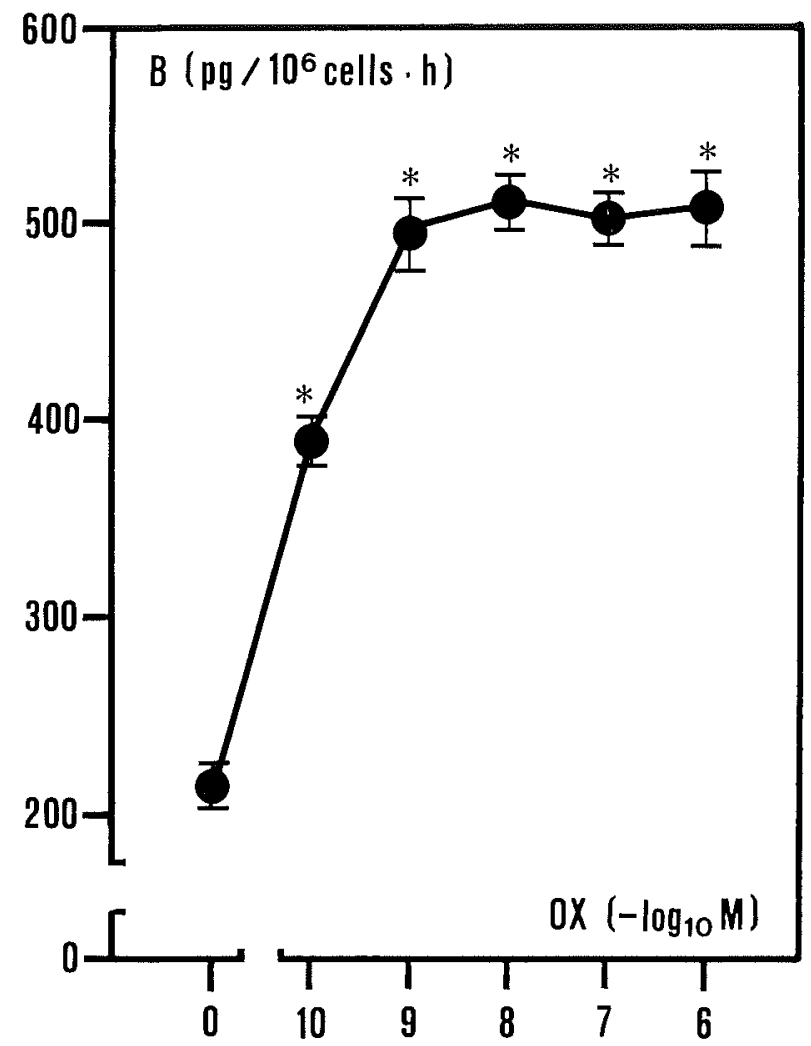

Fig. 1 Effect of oxytocin (OX) on basal corticosterone (B) secretion by isolated rat inner adrenocortical cells. Data are means $\pm \mathrm{SE}(\mathrm{n}=6) .{ }^{*}, P<0.01$ from control group (ANOVA and Multiple Range Test of Duncan)

\section{RESULTS AND DISCUSSION}

Oxytocin markedly enhanced basal corticosterone output by dispersed rat inner adrenocortical cells. The effect was already apparent at a concentration $10^{-10} \mathrm{M}(53 \%)$, and reached its maximum (2-fold) at a concentration $10^{-9}-10^{-8} \mathrm{M}$ (Fig. 1). Videoimaging analysis revealed the existence of a small population of dispersed cells (about 5\%), that responded to oxytocin $\left(10^{-8}-10^{-7} \mathrm{M}\right)$ by a rise (about 2-fold) in the cytosolic free- $\mathrm{Ca}^{2+}$ concentration. A very interesting phenomenon was also observed: single oxytocin-unresponsive cells were moving with the stream of the medium toward an oxytocin-responsive one; after reaching this cell, the non-activated one began to redistribute intracellular $\mathrm{Ca}^{2+}$ achieving the maximum within $30 \mathrm{~s}$ (Figs. 2 and 3 ).

Our present findings clearly indicate that the stimulating effect of oxytocin on corticosterone secretion is due to the direct activation of a small population of dispersed adrenocortical cells, which in turn is able to propagate the secretagogue signal to the large population of oxytocin-unresponsive cells. The propagation of the oxytocin-induced activation appears to be cell-contact dependent, and this could explain why Hinson et al. (2) did not find any effect of oxytocin on corticosterone secretion by collagenase-dispersed rat adrenocortical cells superfused on a Sephadex bed in an isoprene column. It is conceivable that a continuous shaking allows for a continuous transient interaction of suspended cells in the liquid medium, thus leading to the spread of the activation from oxytocinresponsive to oxytocin-unresponsive cells.

Oxytocin stimulates aldosterone secretion by rat zona-glomerulosa cells (2). Hence, we cannot exclude that the small population of oxytocinresponsive cells present in our inner adrenocortical-cell preparations represents zona-glomerulosa cell contamination. However, in our experiments, adrenals have been decapsulated to completely 


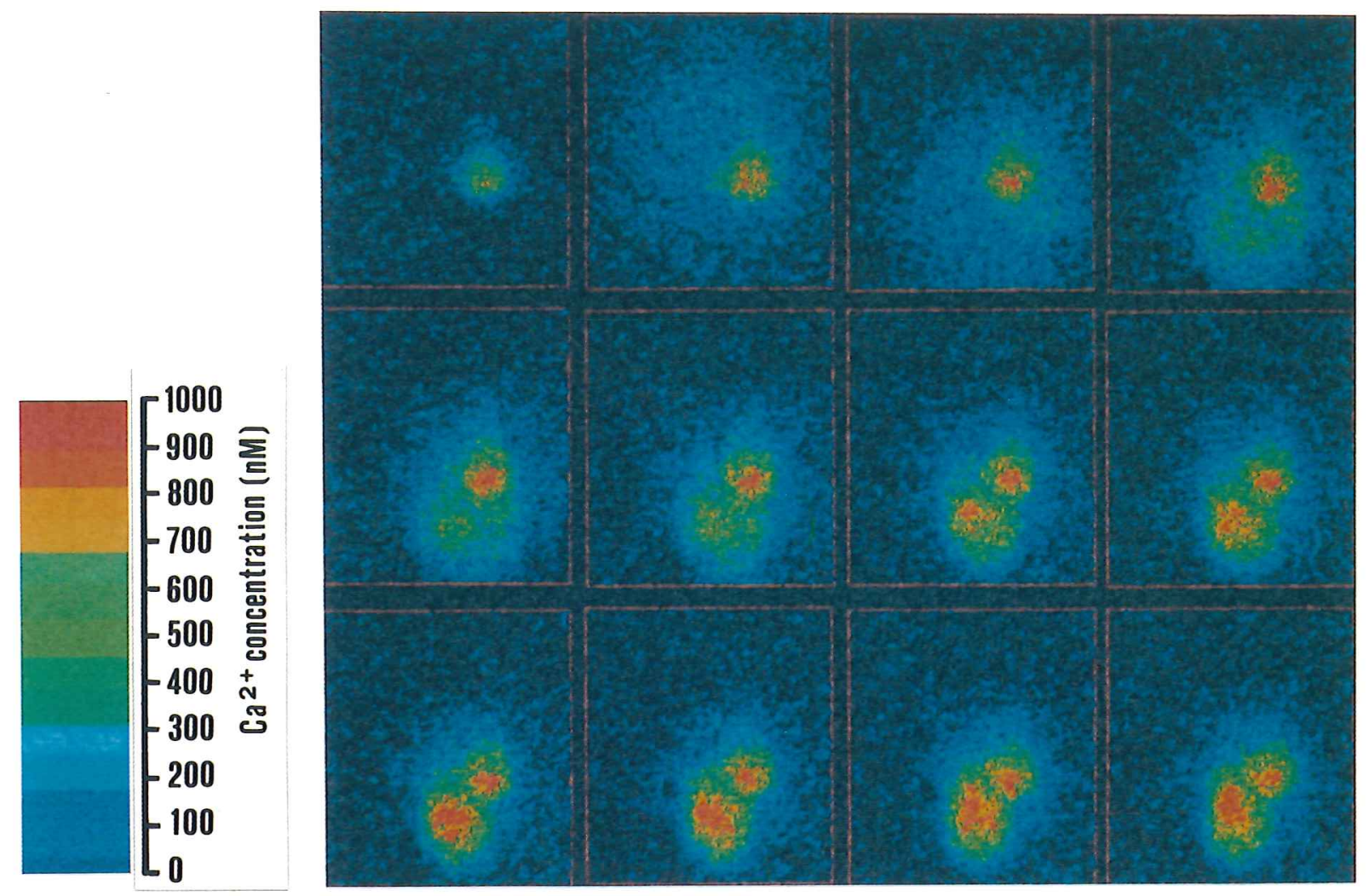

Fig. 2 Video-imaging of oxytocin $\left(10^{-8} \mathrm{M}\right)$ effects on the cytosolic free $\mathrm{Ca}^{2+}$ concentration in isolated rat inner adrenocortical cells. A single oxytocin non-activated cell is moving with the stream of medium toward the activated one; after reaching activated cell, non-activated one begins to redistribute intracellular $\mathrm{Ca}^{2+}$.

remove zona glomerulosa (9), and zona-glomerulosa cells are markedly smaller than inner adrenocortical ones (7), which are very similar to the fluorescent (i.e. oxytocin-responsive) cells of our preparations.

The physiological meaning of our present results remains to be investigated. However, we want to recall that it has been recently shown (3) that physiological concentrations of oxytocin stimulate ACTH secretion by pituitary corticotropes, by mobilizing $\mathrm{Ca}^{2+}$ mainly from intracellular stores.

Received 22 May 1993; and accepted 10 June 1993

\section{REFERENCES}

1. Hawthorn J., Nussey S. S., Henderson J. R. and Jenkins J. S. (1987) Immunohistochemical localization of oxytocin and vasopressin in the adrenal glands of rat, cow, hamster and guinea pig. Cell Tissue Res. 250, 1-6

2. Hinson J. P., Vinson G. P., Porter I. D. and Whitehouse B.
J. (1987) Oxytocin and arginine vasopressin stimulate steroid secretion by the isolated perfused rat adrenal gland. Neuropeptides 10, 1-7

3. Link H., Dayanithi G., Föhr K. J. and Gratzl M. (1992) Oxytocin at physiological concentrations evokes adrenocorticotropin (ACTH) release from corticotrophs by increasing intracellular free calcium mobilized mainly from intracellular stores. Oxytocin displays synergistic or additive effects on ACTH-releasing factor or arginine vasopressin-induced ACTH secretion, respectively. Endocrinology 130, 21832191

4. MALENDowicz L. K. (1993) Involvement of neuropeptides in the regulation of growth, structure and function of the adrenal cortex. Histol. Histopathol. 8, 173-186

5. Malendowicz L. K., Nussdorfer G. G., Markowska A., NowaK K. W. and TorLinski L. (1993) Effects of neuromedin- $\mathrm{N}$ on the pituitary-adrenocortical axis of dexamethasone-suppressed rats. Neuropeptides 24, 1-4

6. Mason W. T., Hoyland J., Rawlings S. R. and RelF G. T. (1990) Techniques and technology for dynamic video imaging of cellular fluorescence. In Methods in Neuroscience (ed. Conn P. M.) Academic Press, San Diego, pp. 109-135

7. Nussdorfer G. G. (1986) Cytophysiology of the adrenal cortex. Int. Rev. Cytol. 98, 1-405 

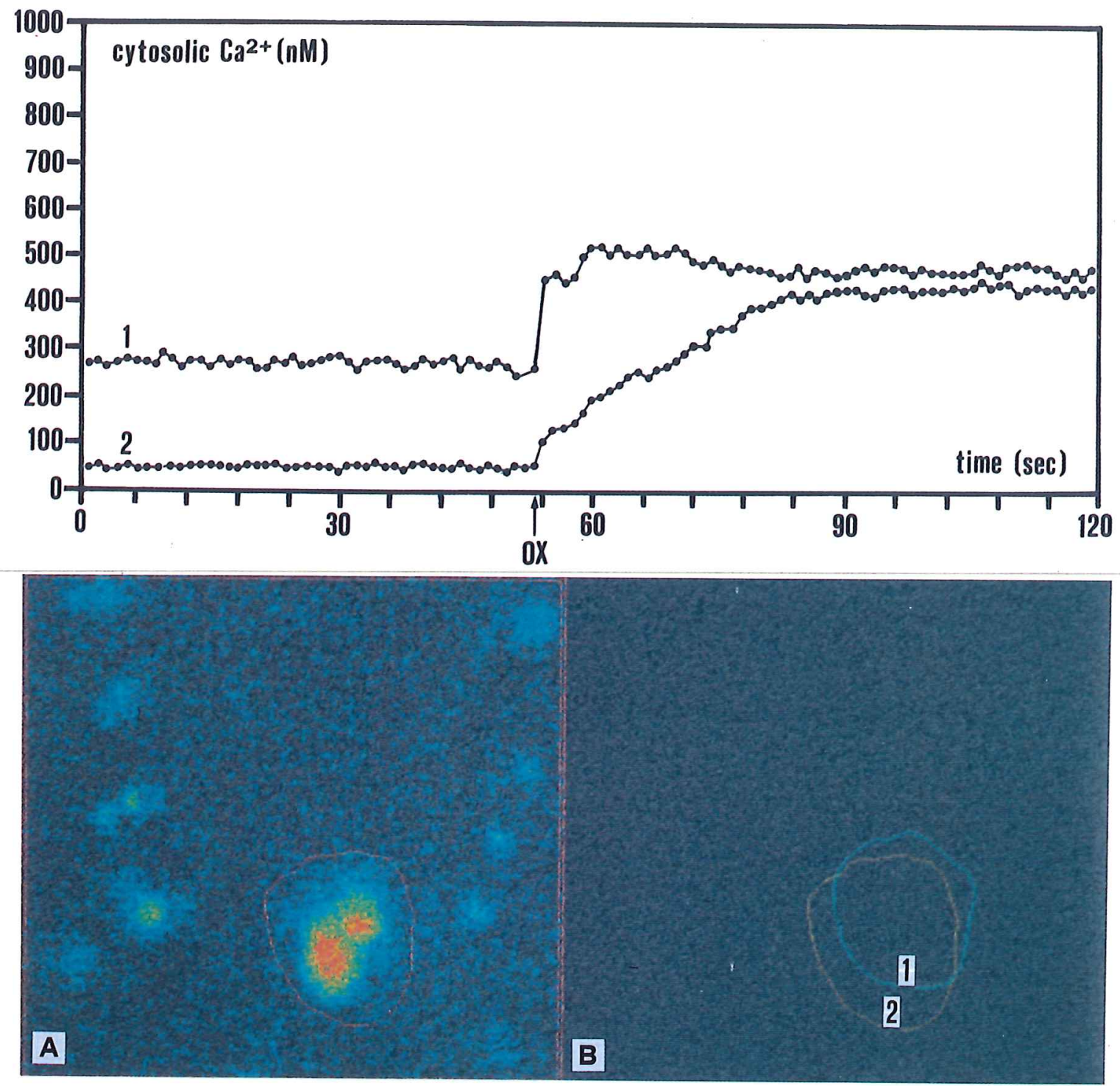

Fig. 3 Effect of oxytocin $(\mathrm{OX})\left(10^{-8} \mathrm{M}\right)$ on $\mathrm{Ca}^{2+}$ redistribution in isolated rat inner adrenocortical cells. Video-imaging record is shown (upper panel), which refers to the oxytocin-responsive (1) and oxytocinunresponsive (2) cells, visualized in the lower panel ( $\mathrm{A}$ and $\mathrm{B}$ ). The record demonstrates that the unresponsive cell displays $\mathrm{Ca}^{2+}$ redistribution upon reaching contact with the responsive one.

8. Szalay K. S. (1981) Effect of pituitary intermediate lobe extract on steroid production by the isolated zona glomerulosa and fasciculata cells. Acta Physiol. Acad. Sci. Hung. 57, 225-231
9. Tait J. F., Tait S. A. S., Gould R. P. and Mee M. S. R. (1974) The properties of adrenal glomerulosa cells after purification by gravitational sedimentation. Proc. Roy. Soc. Lond. B $185,375-407$ 